\title{
Social Mobilisation in the Midst of Social Change: The Case of Traditional Authorities in Ghana
}

\author{
Kwabena Boateng \\ Department of Sociology, University of Ghana; Email: sekyerehene2002@yahoo.com or sekyerehene2002@gmail.com
}

Stephen Afranie

Department of Sociology, University of Ghana; Email: afranie@ug.edu.gh or steveafranie@yahoo.co.uk

\section{Solomon Kofi Amoah}

Institutional affiliation: University of Ghana; Email: samoah10@yahoo.com

\author{
Doi:10.5901/jesr.2016.v6n2p103
}

\begin{abstract}
This study examined the social mobilisation functions of chiefs as partners in socio-economic development. Data were sourced from Juaben Traditional Area in the Ashanti region of Ghana. A qualitative research method was mainly utilized in this study to have a deeper comprehension of the role of chiefs in social mobilisation in the midst of social change. Fifteen participants were purposively sampled and interviewed. A series of interviews and follow-up semi-structured interviews were conducted. The study revealed among other things that by providing the requisite leadership, the paramount chief and his Traditional Council mobilise labour, finances and natural resources in partnership with individuals, local government agencies and private organisations to embark on a number of projects that benefit people in the Traditional Area tremendously. The paper argues that despite their immense developmental roles, chiefs are relegated to the background in the decentralization process. It therefore calls for a greater integration and collaboration between chiefs and local government officials in the planning, execution and monitoring of projects in their communities.
\end{abstract}

Keywords: Social Mobilization, Traditional Authority, Social Change, Development, Land Utilization.

\section{Introduction}

Social mobilization has been used as an effective tool for community development. It is an integral part of process of policy formulation, implementation and enforcement. It attempts to engage people at various levels, including volunteers and professionals, to achieve a purpose. Effective social mobilization brings positive changes in society as it represents a dynamic and participatory process of empowering people to satisfy their socio-cultural, political and economic needs in a sustainable manner. As an act of rallying different stakeholders around common goals social mobilization seeks to facilitate change through a range of players in interrelated and complementary manner (Aryeetey, 2012; UNICEF, 2011)

The range of players whose complementary efforts are rallied in social mobilization include households, communities and their leaders, political leaders and policy makers, state institutions and agencies at various levels of governance, religious leaders and religious associations, NGOs, businesses, service clubs, bureaucrats and technocrats, professional groups etc. (Parks and Lloyd, 2004; UNICEF, 2011). The services rendered through social mobilization include relief items as food, clothing, shelter, health care, during disaster and distress situations; provision of infrastructure and utilities such as education, health, road, water, electricity, irrigation, sanitation etc. (Parks and Lloyd 2004). In recent times social mobilization has become one effective tool to promote good governance and political capital through empowerment of vulnerable groups, partnership building, information dissemination, advocacy and lobbying for policy change. The question is, "is the use of social mobilization something new in the development dynamics in Ghana? Traditional authorities have since the pre-colonial era used this approach as effective tool for development. Through communal labour and other strategies these leaders have used entire communities and members with special skills and competences to achieve different development goals. The study sought to examine the role of traditional authorities in social mobilization amidst the strong currents of social change, particularly, how they have collaborated with other stakeholders including state actors and non-state actors to enhance the living conditions of their subjects. Using the case 
of Juaben Traditional Area in the Ashanti region of Ghana, the paper examines the mobilization capabilities of traditional authorities in Ghana in the midst of significant social change in the country.

\section{Traditional Context of Social Mobilization}

Traditional leaders prior to the advent of colonialism managed the affairs of governance and development in their areas of jurisdiction. The role of traditional authorities included being custodians of resources and mobilization of resources (both human and natural) for the development and welfare of the people. Traditional authorities mobilized their citizens to defend their territory from both internal and external aggressors. They could also organize them for communal labour. Traditional authorities settled disputes among subjects and engaged in law making and served as custodians of cultural heritage (Abotchie, 2006; Brempong, 2007; Rathbone, 2000; Arhin, 1985; Hayford, 1903).

As a symbol of unity, traditional authorities were tasked by tradition and custom, to amalgamate the diverse social organizations within his jurisdiction. In the performance of their administrative functions, traditional authorities are ably assisted by a team of lieutenants who were the political heads of the subordinate units within the traditional area. These subordinate heads who constituted the Council of Elders, consulted their superior leaders whenever faced with difficulties in any form (Busia, 1968: 64). The Council of Elders was to among other things, devise strategies aimed at providing protection and security for the society. The traditional authorities militarily, was the commander-in-chief of the army of his unit and in consultation with the queen mother (Ohemaa) declared war when necessary. By virtue of his significant position as the political head, a traditional authority became the number one target for his opponents during battles and his capture was tantamount to a defeat leading to the surrender of his troops (Assimeng, 1999:170).

The palace of traditional authorities served as courts for dispute settlement. In traditional societies, three court structures existed namely the village courts, divisional and that of the paramount chief or king with the later constituting the supreme court of arbitration (Acquah, 2006:66). Cases migrated within this hierarchy when a disputant dissatisfied with a judgment, invoked the oath of a higher authority within the political establishment. The invoking of the oath corresponded with the summoning at the palace of the ruler whose oath was articulated. Sacrifices were first made to the ancestral spirits before the reason for the invocation of the oath was heard (Arhin, 1985:23).

Revenue in cash and kind was generated judicially. Cases which threatened the collective consciousness of the society, quickly required the purification of the ancestral spirits and the parties provided the sheep needed for this purpose. Disputants also paid an amount to the traditional state before the commencement of a hearing and after careful deliberation and the subsequent pronouncement of judgment, the guilty party paid the faulty fee (mpata) while the innocent party paid the aseda or thanksgiving gift (Arhin, 1985:24-25). Traditional authorities had various punishments at their disposal that commensurate with any offence committed. With a physical military force at their disposal, traditional rulers had the power to punish public offences like suicide, murder and sex with a woman in her menstrual period, which could incur the displeasure of the ancestors. Sanctions at the disposal of the chief included 'death penalty, removal from office, disqualification to hold public office, imposition of fines and ostracism' (Abotchie, 2006:172).

Conceived as the economic power of every society, traditional authorities controlled land utilisation, those who labored on it and everything generated on it (Rathbone, 2000:10). The custodianship role extended to other communal property resources such as water, minerals, etc. which they hold in trust and are accountable to both the ancestors and his living subjects (Alhassan, 2006:531; Boaten, 1994:9; Asenso-Okyere, 1993:3; Busia, 1968). As custodians of economic assets, traditional authorities did not only grant land to those who needed it but ensured the proper exploitation and management of these resources.

Thus before the arrival of colonialists the responsibility of governance and development of most pre-colonized societies rested solely on the shoulders of traditional authorities who were expected to administer their societies appropriately to avert the displeasure of the ancestors who constituted the overloads of the community. The powers and entire development functions of traditional authorities started dwindling at the advent of colonialism and have suffered even harsher casualties in post-colonial constitutional governments (Arhin, 1985:89; Nukunya, 2001:117).

Some social and political commentators have described the traditional institution of governance as anachronistic, riddled with strife and tension. Some have suggested that the institution should either be abolished, modified or made to play marginal role in present day Ghana (Abotchie, Odotei, et al 2006:103; Rathbone, 2000:3). Despite the above representation of the traditional rule, the institution continues to enjoy immense goodwill from the average Ghanaian as the institution attracts individuals from the highest echelons in society (Abotchie, Odotei, et al, 2006:103; Nugent, 1996:204).The decline of chiefly powers is as a result of colonial rule which led to the establishment of western educational structures, the amalgamation of independent ethnic and political groups, monetization of indigenous African 
economy, Christian proselytilsation, establishment of new social structures, etc. (Brempong 2007; Dankwa 2004:5; Nukunya 2001:4; Ake 1981:32-33; Wallerstein 1966:7; Busia 1962).

Much of the powers and functions of traditional authorities have been transferred to elected representatives in the various local government establishments at the local levels to oversee to the general socio-economic development of the various districts and municipal assemblies, which have been established in the country (Rathbone 2010; Brempong 2000; Rathbone 2000). The ramifications of the numerous constitutional evolutions in Ghana ${ }^{1}$ which in effect are reflections of the transformations in traditional rule, the functions of traditional authorities are categorized into two: statutory and non-statutory functions (Brempong 2007:108-113; Brempong 2006:36). Non-statutory functions are those carried over from past and modified by currents of social change. These include settlement of disputes (Afiem in Twi), periodic performance of sacrifices which to a large extent are not patronized by Christians and Moslems within the jurisdiction of the traditional ruler, organization of festivals, etc. (Brempong 2006:108). The statutory functions, on the other hand, are those stipulated in the 1992 Republican Constitution of Ghana following similar provisions in the 1969 and 1979 for traditional rulers to perform (Brempong 2007:38; Brempong 2006:110). The statutory functions in article 270 (3) of the 1992 Constitution include settling disputes that center on the validity of the nomination, election, selection, installation, deposition of a person as a chief/traditional ruler as well as to 'establish and operate a procedure for the registration of chiefs and the public notification in the Gazette or otherwise of the status of persons as chiefs in Ghana'.

With the abolition of their military functions, traditional authorities have now turned their attention to combating the prevalence of high infant mortality rates, pregnancy related deaths, HIVIAIDS, malaria, acute water shortages, lack of access to resources for development, lack of access to viable organisations to represent their interest, the air of despondency and despair which characterise their lives, confront rural folks daily (Seini, 2006:551; Oakley and Marsden, 1983:11).

As managers, traditional authorities collaborate with and through their compatriots and outsiders residing in or out of their territorial establishment to mobilise resources to aid in the materialisation of developmental goals (Abdulai 2006:569). Boaten (1994:3) postulates traditional authorities in their quest to mobilize resources collaboration with developmental partners to improve infrastructure such as roads, schools, health centers, etc. Traditional authorities are therefore an instrumental force of social mobilisation especially in the rural sector. With the mobilization capability at their disposal coupled with the high communal spirit, traditional rulers together with their developmental partners initiate and implement developmental projects which are aimed at improving the deplorable living standards of subjects. It is, imperative therefore, to consider traditional authorities as development partners in the reduction of rural poverty. The paper explores and analyzed the role of Ghanaian traditional authorities in social mobilisation in the midst of the diverse currents of social change that currently characterizes the Ghanaian society.

\section{Literature Review}

One of such very functional responsibility that rested on the shoulders of traditional authorities was social mobilisation. Traditional authorities mobilized people with various skills and competences and resources at their disposal for the enhancement of the socio-economic well-being of their constituents. With the passage of time, traditional authorities mobilized revenue to mitigate the demands of the numerous expansionist campaigns which were wagged. Revenue mobilized were both in kind and in cash and derived from the under listed sources: state enterprise in agriculture and allied activities, trading, taxes; levies and tributes, gifts and loans to the state, court fees etc. (Arhin 1985:63).

Traditional authorities established marketing centres as an avenue of encouraging productive activities and services in their community but also for revenue generation to enhance the general socio-economic development of the community. Traditional Councils actively involved in trading, toll collection from passing traders, custom charges at toll stations in their bid to mobilize revenue. Through effective taxation mechanisms, traditional authorities were able to collect installation tax (of new chief), war tax and those required to purchase items for purification of the shrine and ancestral rooms and to pay for funeral expenses. The funds thus generated were used for diverse purposes such as the purchase of arms and ammunitions, regalia for the chief, loans and gifts for visitors of the states and other societies, festivals and rituals, hospitalities, etc. (Arhin 1985:66-70).

Local government has historically revolved around traditional authorities who prior to the advent of colonialism were the chief executive officer, the magistrate, the commander in chief of community's army, etc. (Ayee 2006; BoafoArthur 2006; Casely-Hayford 1903:32). Traditional authorities as such perform diverse developmental roles including but

1 The 1969, 1979 and 1992 Constitutions of Ghana which underscored the significance of traditional rule and safeguarded this all important institution. 
not exclusive to any of the underlisted activities: developing the human resource potentials of his citizens through education, population control, paying attention to the challenges of women and the vulnerable in society, etc. (Seini 2006:553). The ill-trained and ill-equipped local government officials who are scattered throughout the country have even propelled traditional authorities to take center stage in the fight against poverty and alienation (Seini 2006:551).

With the enactment of the Asante Stool Lands Act (No. 28) of 1958, land ownership which hitherto was vested in the Asantehene was transferred to the Governor General. The Akyem Abuakwa Stool Revenue Act of 1958, likewise, necessitated the appointment of representatives by the Ministry of Local Government to have oversight responsibilities of the use of the revenue gained from lands within this traditional area (Brempong 2006:30; Boafo-Arthur 2006:148149).Despite the fact that the erosion of the economic functions of traditional rulers has hugely decapitated them (Rathbone 2000) traditional authorities in diverse ways mobilize resources for the enhancement of their traditional areas.

Although festivals have diverse significance such as asserting independence, cleansing of the stool rooms, settlement of disputes, pacification of the gods and supplications for fertility and protection, etc. in recent times, festivals are an important revenue generation avenue for traditional rulers to promote businesses and opening remote communities to the global world (Brempong, 2007). With the rejuvenation of festivals celebrations, attempts are made to mobilize 'home boys' resident within and outside Ghana, officials of both central and local government, ambassadors, high commissioners and representatives of development oriented agencies with the view of mobilizing funds for developmental purpose (Brempong 2006:36-37). Traditional authorities on the other outline developmental challenges which confront and to some extent even threaten their existence such as lack of educational facilities, deplorable roads networks linking them to commercial towns, lack of access to hospitals, potable drinking water, etc. (Brempong 2007:90).

On these festive occasions traditional authorities on behalf of their citizens, receive various donations (sponsorships) in cash or kind from corporate bodies and individuals. These funds are channeled into projects aimed at poverty alleviation, thus increasing the living standards of the subjects. Representatives from the central governments for instance use festivals as platforms to publicly outline the government's developmental policies and programmes for the traditional areas (Brempong 2007:90).

Members of the planning committee of these festivals, comprise traditional rulers, the youth president, prominent members of the society and representatives of the District Assemblies organise developmental forums prior to the celebration primarily to mobilize resources for community development (Brempong 2007:90). The committee sets objectives like the provision of social amenities which they hope to provide at the end of the occasion. At the end of the festival, the funds generated are channeled to some of the above mentioned projects. The fundamental aim of festivals therefore, is to solicit funds from both local and international investors for the improvement of traditional areas (Brobbey 2008:36). Among the Asante people, traditional rulers assume presidency on the Town Development Committees.

Recently, the presidential role of traditional authorities on this committee, accords him the middleman position, linking his subjects and the central government or other external bodies who have poverty alleviation high on their agenda. With the introduction of cocoa, traditional rulers among the Asante people led the crusade in the cultivation of this vital cash crop (Boaten 1994:9). The traditional authority was thus a pivot around which developmental initiatives such as the provision of primary schools, health facilities evolved with the aim of improving the living standards of his subjects (Boaten 1994:15). Although rites are performed during these festivals, their significance are usually secular in character. The concluding parts of these occasions are usually characterized by the 'harvest' or fund raisings where at times community members voluntarily donate farm produces to be sold to fund developmental projects in the community(Brempong 2007:91). In order to be admired by hissubjects and regarded as successful, a traditional ruler must effectively mobilize resources and liaise with developmental partners to alleviate the plight of his people (Brempong 2006:37).

Boafo-Arthur (2006) sought to map out some challenges the institution faces as well as some responses the institution has evolved in its quest to ensure its existence in the face of these numerous challenges. In this millennium where rapid socio-economic development has been the preoccupation of government, traditional rulers and their Traditional Councils, as custodians of communal property resources like land, can effectively assist central governments in charting the developmental path.

Traditional rulers such as the Asantehene Otumfou Osei Tutu II and Osagyefo Amoatia Ofori Panin of Kyebi are role models to many of their colleagues. These two individuals, have been instrumental in mobilizing resources to develop their subjects (Boafo-Arthur 2006:160). The Asantehene through his instrumentality, mobilized resources which has yielded in the establishment of an Educational Fund, which seeks to carter for the educational needs of brilliant but needy students from the basic to the tertiary levels. Although the Otumfuo Education Fund as it is referred to, was initially established to enhance the low educational standards in Asanteman (Asante Kingdom), beneficiaries have indeed not 
only come from Asante but from other parts of Ghana.

About two thousand $(2,000)$ children have benefitted from resources mobilized by the Asantehene from local and international organizations as well as Ghanaians overseas. To help improve the health conditions of people under his jurisdiction, Otumfo Osei Tutu II, established a health Committee to device strategies aimed at combating the deadly HIVIAIDS pandemic. This committee also works closely with the Regional and Metropolitan Medical Team to mobilize resources and support for the eradication of infant mortality, elimination of glaucoma and other eye diseases, buruli ulcer, guinea worm and other water-borne diseases'2. The Golden Development Holding Company (GDHC) was set up 'to catalyze economic development by identifying viable projects, mobilizing investment resources and helping to improve investment profile and climate of Ashanti' ${ }^{3}$. Osagyefo Amoatia Ofori Panin on the other hand, has painstakingly, endeavored to arrest deforestation and the HIVIAIDS menaces in the country. He has mobilized resources and personally participated in campaigns organized to educate people on the dangers of HIVIAIDS aimed at minimizing its spread.

During the Golden Jubilee of the Restoration of the Asante Union in 1985, the late Asantehene Otumfuo Opoku Ware II, instituted the 'progress (Nkosoo) stool for non-royal elite, well-educated business men (Akrong 2006:208; Steegstra 2006; Brempong 2007:59). Two fundamental reasons can be advanced for creation of a stool purposely designed for development. The first is the projection of the late King that the numerous overseas travels by numerous Ghanaians will enable them gain access to international networks and funds for development. The second reason was informed by the creation of ministers in some Western countries purposely for international development (Steegstra 2006:607). Thus, the basic rationale is that these non-hereditary traditional authorities with their professional and educational experience, are better positioned to help chart the developmental agenda of the communities and that their ability to mobilize funds from their compatriots in the diaspora will go a long way to alleviate poverty in rural communities.

Those installed as Nkosoohene have often been working abroad or are having international networks and at times became involved in their new societies through the execution of their jobs. After their installation, they become fully immersed into the culture of their new societies and are expected to continually contribute to the socio-economic enhancement of his subjects. The concept of development chiefs has been incorporated into the political establishment of many ethnic groups in Ghana (Brempong 2007:59). Among the Dangme and Ewe speaking communities in southern Ghana for instance, a development traditional ruler is referred to as Manoryam and Ngoryifia respectively (Steegstra 2006:607). The creation of this honorary title by the late Asantehene and its subsequent introduction into other traditional areas, has brought some degree of transformation into the institution.

Although the Nkosoo stool was originally instituted for Ghanaians only a navigation through the traditional political system in Ghana will illustrate that both Ghanaians and foreigners with diverse professional and educational backgrounds have risen to the stool. There has been an attempt recently, for towns to have a white development chief or queen mother to facilitate the pace of community development leading to an abuse of this laudable initiative in chieftaincy (Steegstra 2006:612). It must be stated that the installation of honorary titles onto foreigners did not originate with the inception of the development stool or is not a recent phenomenon in Ghana (Steegstra 2006:607). The incorporation of foreigners into the political system of some ethnic groups in Ghana is not a recent phenomenon. Historically, Hausa traders have been incorporated into the political establishment of the Akans for instance around the $19^{\text {th }}$ century (Fierz 2003 cited in Steegstra 2006:607).

Others are awarded with the Nkosoo title based on their outstanding contributions towards poverty alleviation within the community they have been installed while others on a perceived assumption that they will be better positioned to mobilize adequate funds for developmental projects (Brobbey 2008:83; Steegstra 2006:612). They either use their own funds or mobilize funds from their compatriots by orienting them about the developmental needs of the members of their new hometowns. In their quest to ensure accountability, those who mobilize revenue from individuals and other developmental agencies, render detailed reports about the progress of the projects they donated towards.

The desire for development traditional authorities to facilitate the pace of socio-economic development, has created a tendency in which proper investigations into the backgrounds of these individuals are not adequately done. This has allowed unscrupulous individuals into traditional rule bringing the institution to disrupt. However, the process of broadening the horizon of chieftaincy by way of including experts in the institution, could positively reform the political structures and the revenue base of traditional rulers to meet the developmental needs of their subjects (Akrong 2006:209). Thus, the transformations the traditional rule has witnessed by way of the incorporation of development stools into its structures is illustrative of the fact that the institution is flexible and can adapt to change (Steegstra 2006:619).

${ }^{2}$ www. africandevelopmentforum.com

${ }^{3}$ Cited in West Africa 29th April - 5th May 2002, p.25 Also cited in Boafo -Arthur, 2006 p.163 
Notwithstanding the fact that Akrong (2006) illustrated how the institutionalization of the nkosos system seeks to enable traditional authorities meet the developmental needs of their subjects, failure to account for how the numerous projects initiated by the development chiefs have enhanced the livelihoods of the rural folks and how these projects have been managed and maintained against the backdrop of the poor maintenance culture of some communities were overlooked. Steegstra (2006) also did not recast his lenses on the projects that some of his respondents have implemented, their cost, management and the impacts they have on beneficiary communities.

\section{Study Area and Methodology}

Juaben, the focus of this study is located in the Ashanti Region of Ghana. Administratively, the study area falls within the Ejisu-Juaben Municipal Assembly with Ejisu as the Municipal capital. The Municipality has a population of one hundred and forty-three thousand, seven hundred and sixty-two people with an Akan majority while the remaining population is made composed of nine percent (9\%) of people of northern extraction, Ewes $5.4 \%$ and Gas $(1 \%)^{4}$.As one of the principal towns, Juaben has an urban status ${ }^{5}$ with an estimated population of nine thousand and eighty-five $(9,085)$. Four thousand, three hundred and fourteen $(4,314)$ are males while the female population is four thousand seven hundred and seventy-one $(4,771)^{6}$.

The Municipality has two paramount areas namely, the Juaben Traditional Area and the Ejisu Traditional Area who pay homage to the Asantehene, ruler of the Asante kingdom. The inhabitants of Juaben are part of the Akan ethnic group who have historically fashioned a centralised political administrative system. In Ghana, the Akans are located in the Brong-Ahafo, Ashanti, Central, Eastern, Western and Northern Volta Regions of Ghana (Brempong 2007: 10). They speak a fairly intelligible dialect of a common language which comprises the following: Asante, Fante, Agona, Brong, Akyem, Akwapem, Kwahu, Denkyira, Assin, Ahanta and Nzema-Evalue (Arhin 1985:13).

Historically Adanse is the ancestral home of the people of Juaben; migrating and settling at Asumenya, Asantemanso and finally to their current location near Kumasi. During the formative periods of the Asante kingdom, Juaben as a principal Oyoko state was instrumental in the numerous expansionist wars that the founders of the kingdom embarked ${ }^{7}$. However, two destructive civil wars that broke up between Juaben and Asanteman in 1832 and $1875^{8}$ had left a devastating imprint on Juaben (Osei 2002:155) with the members of the Juaben royal house migrating to Akyem Abuakwa (Brempong 2007:114).

A qualitative research method was mainly utilized in this study to have a deeper comprehension of the role of chiefs in social mobilisation in the midst of social change. This type of research thus increasing our comprehension of why things are the way they are in our social world and why people act the way they do. Purposive sampling involves the selection of specific units or cases based on specific purpose or objective of a study (Tashakkori and Teddie, 2003). Purposive sampling was used to select participants who were engaged in in-depth qualitative interviews. Purposive sampling and qualitative interview were used because the subject of interest is in a particular context that required the comprehensive engagement of some category of persons who have knowledge and experience in the role of traditional leadership in social mobilization. Thus traditional authorities and local government actors who are involved in social mobilization, were purposely sampled and interviewed. The sample thus consisted of the Paramount Chief (Omanehene) of the Juaben Traditional Area Nana Otuo Siriboe II, the current queenmother and Nana Juaben Serwaa II, former Queen and King of Juaben State (1959-1963), three (3) sub-chiefs and the Clark of the Juaben Traditional Area.

The remaining participants were the Municipal Chief Executive of Ejisu Juaben Municipality, the Municipal Coordinating Director, and the Presiding Member of the municipal assembly, the current and former assembly members of Juaben, the Community Development officer, the President and secretary of the Town Development Committee of Juaben. In all, fifteen participants were purposively sampled for this study. A series of interviews and follow-up semistructured interviews were conducted with the participants. The primary data generated were supplemented with secondary / documentary data.

\footnotetext{
${ }^{4}$ Ghana Statistical Service 2010 Population and Housing Census

${ }^{5}$ www.ghanadistricts.com

${ }^{6}$ Ghana Statistical Service 2010 Population and Housing Census p. 18

7I appreciate discussions held with Nana Juaben Serwaa II, former Queen and King of Juaben State (1959-1963) on the history of Juaben on 27th October, 2009.

${ }^{8}$ Silver Jubilee Brochure of Nana Otuo Siriboe II, p.4
} 


\section{Results and Discussion}

Traditional authorities, the study revealed, have actively collaborated with other development partners through which resources have been mobilised to initiate numerous projects in the Juaben Traditional Area. Participants interviewed outlined Juaben Oil Mills and Palm Plantation, Juaben Oil Palm Outgrowers Co-operative Society (JOPOCOS), the Juaben Government Hospital and Juaben Rural Bank (JRB) were initiated in consultation with some development partners. Traditional authorities have engaged in diverse economic ventures and in some cocoa producing communities, traditional rulers were at the forefront in the cultivation of this cash crop. The paramount ruler of Juaben, Nana Otuo Siriboe II, with this orientation and in collaboration with the Juaben Rural Bank and other developmental partners, purchased the State Oil Palm Plantation at Juaben when the central government decided to diversify the company ${ }^{9}$. This initiative was intended to enable members of his traditional area engage in economic ventures to enhance their living standards. The facility employs three hundred and fifty (350) workers comprising ninety-eight (98) females and two hundred and fifty-two (252) males.

Established in 1998, the paramount objective of the Juaben Oil Palm Outgrowers Co-operative Society (JOPOCOS) is to motivate a group of loyal farmers to produce palm fruits to feed the oil palm factory to ensure the constant operation of the factory. The society thus complements what private producers sell to the factory. The Omanhene and his Council of Elders were able to mobilize a loan of Seven Hundred thousand US dollars $(\$ 700,000)$ from the World Bank in 1998 the Agric Development Programme (AGDIV) under the Ministry of Food and Agriculture (MOFA). About two thousand two hundred dollars $(\$ 2,200)$ was allocated for the construction of a modern office complex to see to the administrative aspects of the farmers. The loan was to enable the materialization of the objectives of JOPOCOS. The Juaben Rural Bank (JRB) was to disburse the loan to interested farmers. The loan enabled the distribution of logistics such as fertilizers, boots, rain coats, cutlasses, clearing charges of the land to farmers. Also, management of the Juaben Oil Mill bears the transportation cost of harvested fruit from the farm to the factory.

The Juaben Government Hospital was jointly established by the School of Medical Sciences of the Kwame Nkrumah University of Science and Technology (KNUST) and the Juaben Traditional Council in 1988 and later the Ministry of Health (M.O.H) to serve as the District Hospital for the Ejisu-Juaben Municipal Assembly in Ashanti Region ${ }^{10}$. With an estimated cost of fifty million old Ghana cedis, the hospital was officially commissioned by the late Asantehene, Otumfuo Opoku Ware II. The facility has a Maternity Ward, Children's Ward and the General Ward. The women of Juaben led by the queen mother have adopted the Children's Ward where periodic cleaning and donations are made to the admitted children. Thus, the hospital has a twenty-four (24) hour uninterrupted service in reproductive and child healthcare. Additionally, the hospital offers maternity, surgery, laboratory, dispensary and In and Out Patient admissions. The management of the hospital in conjunction with the Juaben Traditional Council and the government had planned to undertake projects such as a Health Assistant Clinical Training School (HAC), a Medical Research Centre and the expansion of admission wards. The Traditional Council has released about thirty (30) acres of land to facilitate the materialization of the Health Assistant Clinical Training School (HAC) project. The school when completed will increase the needed health professionals in the country.

In recent times, traditional authorities embark on business trips to foreign lands with the principal aim of attracting foreign investors and non-governmental agencies to develop their communities. The Juabenhene Nana Otuo Siriboe together with some members of his Council, periodically travel abroad to encounter compatriots and foreign investors to mobilize revenue for community development. Traditional authorities have received funds from citizens in the Diaspora which have been utilized in the number of development projects undertaken in the Traditional Area. In March 1972, Nana Otuo Siriboe II met with members of the Juaben Youth Association based in Accra and Tema and assured them of his desire to improve the living standards of his subjects. The Omanhene recounted the immense assistance the citizens through the Juaben Youth Association in the construction of school blocks, latrines, culverts and drains in the township.

Nana Akyamaa III, queen mother of Juaben in an interview, recounted the immense role her subjects in the diaspora have played in the establishment of the Juaben Government Hospital. For instance in August 2004, Juaben citizens in the United Kingdom donated a Benz ambulance to the Juaben Government Hospital ${ }^{11}$. A number of subjects have also donated medical equipment to the hospital to enhance the work of the staff in health care delivery. In 2004, a philanthropist called Dr. Fred Kofi Boadu, a Professor at the Duke University and a citizen of Juaben made financial donations towards the renovation of the old Surgical Theater and the purchase of a water reservoir to enhance water

\footnotetext{
${ }^{9}$ Silver Jubilee Brochure of Nana Otuo Siriboe II, p. 23

10 Juaben Government Hospital, 2004 Annual Report

11 Juaben Government Hospital, 2004 Annual Report p.14
} 
supply in the hospital. Through these foreign travels, the Traditional Council has been able to mobile a team of medical doctors comprising expatriates and citizens of Juaben who visit the traditional area yearly to undertake medical screening and other health related tasks in collaboration with the medical staff at the Juaben Hospital. The medical team in August 2008 for instance, distributed over one thousand treated mosquito nets within Juaben Ofoase, Dumakwai, Bamfo and Yaw Nkrumah. The traditional authority of Dumakwai, one of the communities within the traditional area, donated twenty mattresses to the hospital in November 2004 alone ${ }^{12}$. The queen mothers association in the traditional area in collaboration with the public health division of the Juaben Government Hospital periodically organise health education seminars for the women in traditional area.

In 1984, the Omanhene of Juaben Traditional Area, mobilized funds from his subjects to commence a rural bank in the traditional area. Through the initiative of the Omanhene, the bank was able to have its own premises prior to its inauguration and has now been upgraded to the status of a Rural Bank by the Bank of Ghana. Here again, in the construction of the building, the Traditional Council was responsible for the financial cost. Citizens were encouraged to purchase shares of the bank when it was floated to the general public to buy. By virtue of population expansion, there has been the need to reestablish the police station which was functional under Nana Otuo Siriboe I. the police station project which is near completion has been funded solely by the Juaben Traditional Council with local labour being utilized. In collaboration between the Judicial Service, the Traditional Council has been able to reestablish a court which was constructed between 1925 and 1926. This court was commissioned by the Chief Justice Her Ladyship Georgina Wood in March 2009. Mention must be made that in the construction of the numerous projects the Traditional Council and other development partners have undertaken in the area, the traditional rulers organized their subjects who provided the labour to speed up the projects through communal labour.

The role of non-governmental agencies in community development in Ghana and elsewhere cannot be overemphasized (Badu and Parker 1992:28; Boaten 1994). One NGO which has tremendously transformed the lives of the people of Juaben is DANIDA. This organization sponsored the Traditional Council in its water supply project which after its completion continues to provide about thousand gallons of water daily to the inhabitants of Juaben and its environs. Also, the Community Water Agency, a non-governmental organization in collaboration with the Traditional Council and the District Assembly extended water supply in the area. Regarding the financial commitment, the Traditional Council and the Municipality provided five percent (5\%) each of the cost while the agency absorbed the rest. Periodic assistance from the Voluntary Work Camps Association is sought by the Juaben Traditional Council in developing the traditional area. In the construction of street drains and a four-classroom block for the Local Authority Basic Schools for instance, sixty-three (63) volunteer corps including twenty-six (26) foreigners actively participated in the exercise ${ }^{13}$.

Traditional authorities have the responsibility for mobilizing resources for community development. These Traditional Leaders in consultation with their Council of Elders may single handedly initiate development projects and secure the financial or technical support from both internal and external sources for their execution. Funds are internally mobilized through the sale of stool lands and royalties derived from concessionary rights from companies who work on lands belonging to a stool. Periodically, subjects of Juaben annually pay levies for development purposes especially during the celebration of Odwira festival and other festive occasions such as Easter holidays where subjects from both home and diaspora contribute resources for developmental purposes ${ }^{14}$.

The essence of the country's decentralization policy is to fast track participatory community development through resource mobilisation at the local level (Ahowi 2010; Aryee 2006). Traditional authorities in Juaben have collaborated with the Ejisu-Juaben Municipal Assembly on numerous occasions to enhance the livelihoods of the subjects within the Traditional area. Through the department of community development, communities are able to undertake self-help projects such as building of school blocks, construction of feeder roads, sinking bore-holes for potable water, and building hospitals and community centres. Some of the projects of the Assembly demand 'counterpart funding' in which the costs of projects are shared in this case, between the Traditional Council and the Assembly; a classical point is illustrated during the extension of water supply in the Juaben traditional area. Local government officials also collaborate with the Traditional Council to organise developmental durbars, where financial assistance is sought from the subjects ${ }^{15}$. The study also confirmed findings by Dawda and Dapilah (2013) who underscored the collaboration between traditional rulers and local government actors in the evolution of developmental projects and policies.

\footnotetext{
12Juaben Government Hospital, 2004 Annual Report p. 14

${ }^{13}$ Silver Jubilee Brochure of Nana Otuo Siriboe II, p.16

${ }^{14}$ The Ghanaian Times April 7, 1972

${ }^{15}$ We appreciate discussions held with Mr. Solomon Asiedu, the Municipal Coordinating Director of Ejisu-Juaben Municipal Assembly on June 5, 2009 at his office.
} 
With the absorption of much of the functions by the central government and its apparatus at the local level where the traditional ruler's authority is much felt, traditional rulers have in recent times, strengthened their developmental functions, becoming agents of development in collaboration with other developmental partners inclined towards poverty reduction (Boateng 2010; Boafo-Arthur 2006). The findings of the present study collaborate those of Brempong (2007), Boaten (1994) and Arhin (1985) who also revealed that traditional authorities have customarily engaged in economic activities.

\section{Conclusion and Recommendations}

The study analyzed the role of traditional leaders in social mobilization for development. Despite the erosion of the powers and functions of traditional authorities into the hands of elected non-hereditary actors within the local government system, traditional authorities continue to be instrumental forces in socio-economic development. In their bid to speed up the pace at which projects are completed, traditional leaders usually provide land, building materials and communal labour needed to execute these projects. As managers of communal property resources within their jurisdictions, traditional authorities are expected to mobilize and integrate their subjects into the formulation, and materialization of projects in their communities. As managers, traditional leaders mobilize resources together with their development partners such as the government and nongovernmental organizations in the realization of their developmental goals.

As the paper reveals traditional authorities from the study area are able to mobilize resources from subjects both at home and in the diaspora, and other developmental partners which they utilize in the numerous projects undertaken by the Juaben Traditional Area. Despite their immense developmental roles and their capacity to mobilize resources within and outside their traditional areas, traditional authorities are not duly recognized in the local government system which has the primary developmental responsibility at the local level where the traditional rulers' significance is paramount. It is therefore imperative that policy and research be devoted to how traditional authorities can be properly integrated into the local government system where their rich expertise could be utilized to enhance efforts aimed at poverty reduction and development at large.

\section{References}

Abdulai, A.K. 2006. 'The Ghanaian Chief as a manager: Between tradition and modernity' in Odotei, I.K and Awedoba, A. (Ed) Chieftaincy in Ghana: Culture, Governance and Development Accra Sub-Saharan Publishers pp.565-585.

Abotchie, C. 2006. 'Has the position of the Chief become anachronistic in contemporary Ghanaian politics?' in Odotei, I.K and Awedoba, A. (Ed) Chieftaincy in Ghana: Culture, Governance and Development Accra Sub-Saharan Publishers pp.169-191.

Abotchie, C, Awedoba, A \& Odotei, I.K 2006. 'Perceptions on Chieftaincy' in Odotei, I.K and Awedoba, A. (Ed) Chieftaincy in Ghana: Culture, Governance and Development Accra Sub-Saharan Publishers pp.103-143.

Acquah, G.K. 2006. 'The Judicial role of the chief in democratic governance' in Odotei, I.K and Awedoba, A. (Ed) Chieftaincy in Ghana: Culture, Governance and Development. Accra. Sub-Saharan Publishers pp. 65-79.

Ahwoi K. (2010). Local Government and Decentralization in Ghana. Unimax Macmillan Ltd. Hong Kong

Ake, C. 1981. A Political Economy of Africa. Longman. Nigeria.

Akrong, A. 2006. 'Religion and Traditional leadership in Ghana' in Odotei, I.K and Awedoba, A. (Ed) Chieftaincy in Ghana: Culture, Governance and Development. Accra. Sub-Saharan Publishers pp. 193-212.

Alhassan, O. (2006). 'Traditional authorities and sustainable Development:Chiefs and Resources management in Ghana' in Odotei, I.K and Awedoba, A. (Ed) Chieftaincy in Ghana: Culture, Governance and Development Accra Sub-Saharan Publishers pp. 527546.

Arhin, K.1985. Traditional Rule in Ghana: Past and Present. Accra. Sedeco Publishing Limited.

Aryeetey, E.B.D. 2012: The Act of Giving Through Volunteerism and Philanthropy: The Ghana Experience, CSPS Working paper series No.2/12.

Asenso-Okyere, W. Kwadwo, Atsu, S.Y (1993) 'Communal Property Resources in Ghana Policies and Prospects. Discussion Paper Number 27 Legon: ISSER, University of Ghana.

Assimeng, M. (1999). Social Structure of Ghana. Ghana Publishing Corporation.

Ayee, J.R.A. 2006. 'Some thoughts on the institutional representation of chiefs in the District Assemblies and the Sub-District Structures' in Odotei, I.K and Awedoba, A. (Ed) Chieftaincy in Ghana: Culture, Governance and Development. Accra. Sub-Saharan Publishers pp. 55-63.

Badu Y. A. and Parker, A. (1992) 'Role of Non-governmental Organisation in Development: The Case of the Voluntary Workcamps Association of Ghana.Institute of African Studies Review (NS) Vol.8 Nos1 \& 2.

Boafo-Arthur, K. 2006. 'Chieftaincy in Ghana: Challenges and prospects in the 21st century' Odotei, I.K and Awedoba, A. (Ed) Chieftaincy in Ghana: Culture, Governance and Development. Accra. Sub-Saharan Publishers pp. 145-168.

Boaten, B. A. 1994. 'Chieftaincy in Ghana- An Overview'. Legon: Institute of African Studies, University of Ghana. (Mimeo). 
Brempong, A. 2007. Transformation in Traditional Rule in Ghana, 1951-1996. Accra. Sedeco Publishing Limited.

Brempong, A.2006. 'Chieftaincy, An Overview' in Odotei, I.K and Awedoba, A. (Ed) Chieftaincy in Ghana: Culture, Governance and Development Accra Sub-Saharan Publishers pp.27-42.

Brobbey, S.A.2008.The Law of Chieftaincy in Ghana: Incorporating Customary Arbitration, Contempt of Court, Judicial Reviews. Advanced Legal Publication AccraGhana.

Busia, K. A. 1968. The Position of the Chief in the Modern Political System of Ashanti. Frank Cass and Company Limited.

Busia, K. A. 1962. The Challenge of Africa. New York. Frederick A. Praeger Publishers.

Casely-Hayford, J. E. 1903. Gold Coast Native Institutions. London: Sweet \& Maxwell.

Dankwa, A.2004. The Institution of Chieftaincy in Ghana: The Future. KonradAdeauer Foundation. Accra. Ghana.

Dawda, Tanko, D. and Dapilah, Frederick. 2013. Challenges of the Collaboration between Formal Local Government Actors and the Chieftaincy Institution in Ghana: Lessons from the Sissala East District of the Upper West Region of Ghana. International Journal of Humanities and Social Science Vol. 3 No. 12 [Special Issues -June 2013].

GSS (2002). Ghana Population and Housing Census Report. Accra. Medialite Company Limited.

Nugent, P. (1996) 'An Abandoned project? Journal of Legal Pluralism and Unofficial Law pp37-38.

Nukunya, G.K. 2001. Tradition and Change in Ghana. Ghana Universities Press.

Osei, K. 2002. A Handbook on Asante Culture. Kumasi. Cita Press Ltd

Oakley, P. \& Marsden. 1990. Approaches to Participation in Rural Development'. Geneva. International Labour Organisation

Parks W. and Lloyd, L. 2004.Planning Social Mobilization and Communication for Dengue Fever Prevention and Control, A Step-By-

Step Guide, For WHO Mediterranean Centre for Vulnerability Reduction(WMC), UNDP/World Bank/WHO Special Programme for Research and Training in Tropical Diseases (TDR)

Rathbone, R. 2000.Nkrumah and the Chiefs: The politics of Chieftaincy in Ghana 1951-60. Ohio University Press.

Seini, W.A. 2006. 'The role of traditional authorities in rural development' in Odotei, I.K and Awedoba, A. (Ed) Chieftaincy in Ghana: Culture, Governance and Development Accra Sub-Saharan Publishers pp. 547-564.

Silver Jubilee Celebration of the enstoolment of Nana Otuo Siriboe II, October 1996. Accra. Commercial Associates Limited.

Smith, D. A. 1976. Social Change: Social theory and historical processes. Longman. London.

Steegstra, M. 2006. 'White Chiefs and Queens in Ghana: Personification of 'Development'in Odotei, I.K and Awedoba, A. (Ed) Chieftaincy in Ghana: Culture, Governance and Development Accra Sub-Saharan Publishers pp. 603-620.

Tashakkori, A., and Teddlie, C. (Eds.). (2003a). Handbook of mixed methods in social \& behavioral research. Thousand Oaks, CA: Sage.

The Ghanaian Times, 7 April 1972

UNICEF.2011. Communication for Development (CAD) http://www.unicef.org/cbsc/index_42347.html

Wallerstein, I. M. (1966). Social Change, the Colonial Experience. New York. John Wiley \& Sons Inc. Unpublished Documents

Juaben Government Hospital, 2004 Annual Report 